\title{
Influence of Entrepreneurial Characteristics on the Organizational Performance of Incubated Companies
}

Influência de Características Empreendedoras no Desempenho Organizacional de Empresas Incubadas

\author{
Sabrina do Nascimento ${ }^{1}$, Amelia Silveira² e Suzete Antonieta Lizote ${ }^{3}$ \\ ${ }^{1}$ Universidade do Oeste de Santa Catarina, UNOESC \\ ${ }^{2}$ Universidade Federal da Santa Catarina, UFSC \\ ${ }^{3}$ Universidade do Vale do Itajaí, UNIVALI
}


Abstract

The work analyzed the influence of entrepreneurial characteristics (entrepreneurial self-efficacy, entrepreneurial intention anda capacity for innovation) on the organizacional performance of incubated companies in Santa Catarina. The research was descriptive using a quantitative method. The data analysis adopted the structural equation modeling and the partial least squares adjustment technique (SEM/PLS). The four research hypotheses were accepted. The associations of entrepreneurial self-efficacy with entrepreneurial intent and with the capacity for innovation stood out, being in both cases positive and very significant. The links between entrepreneurial intent and the capacity for innovation with organizacional performance also proved to be significant. However, its significance was less. The results adhered to the model of Chell (2008), allowing to affirm that the psychological, sociological and economic components were interrelated when considering the entrepreneurial personality. It was concluded that the study of the actions of the entrepreneurs must be carried out from a multidimensional perspective.

Keywords: entrepreneurial self-efficacy, entrepreneurial intention, innovation capacity, organizational performance

\section{Resumo}

O trabalho analisou a influência das características empreendedoras (autoeficácia empreendedora, intenção empreendedora e capacidade de inovação) no desempenho organizacional de empresas incubadas de Santa Catarina. A pesquisa foi descritiva utilizando método quantitativo. A análise dos dados adotou a modelagem de equações estruturais e a técnica de ajustamento por quadrados mínimos parciais (SEM-PLS). As quatro hipóteses de pesquisa foram aceitas. Destacaram-se as associações da autoeficácia empreendedora com a intenção empreendedora e com a capacidade de inovação, sendo em ambos os casos positiva e muito significativa. Os vínculos da intenção empreendedora e da capacidade de inovação com o desempenho organizacional também se mostraram significativos. Entretanto, sua significância foi menor. Os resultados aderiram ao modelo de Chell (2008), permitindo afirmar que os componentes psicológicos, sociológicos e econômicos estavam inter-relacionados ao considerar a personalidade empreendedora. Concluiu-se que estudo das ações dos empreendedores deve ser realizado desde uma perspectiva multidimensional.

Palavras-chave: autoeficácia empreendedora, intenção empreendedora, capacidade de inovação, desempenho organizacional 
Researchers conducted in the entrepreneurship area have undergone a metamorphosis due to concepts from other knowledge areas. Thus, Sociology, Anthropology and Business Strategy, among others, have extended their background, and the consequences of these changes can be seen in the study field (Thomas \& Mueller, 2000). In the field of organizational studies, there are numerous researches aimed to understand the role of the entrepreneur, for example, as in Shane and Venkataraman (2000), and Baker \& Nelson (2005).

Lenzi (2008) asserts that the approaches brought from the behaviorist, physiological and functional positive schools and from the cognitive mapping promote synergy in the entrepreneurs' actions assessment. In line with this thinking, the study by Chell (2008) looks toward the understanding of the entrepreneurs' personality from a combination of concepts taken from psychology, sociology, and economics. According to the author, people live immersed in a social environment which results, in general terms, that their actions and behaviors are interconnected through a socially constructed framework of social norms, rules, and responsibilities. These are also limited to a system of the economic, political and legal system of rules and regulation.

To understand and discuss the entrepreneurial personality, Chell (2008) visits different areas of knowledge to draw disciplinary approaches that permeate the entrepreneur attributes. In this perspective, she reinforces the importance of recognizing the political and socioeconomic context in which entrepreneurship is practiced, as well as the entrepreneurial characteristics involving these individuals. According to her work, the disciplinary approaches that permeate the particularities of individuals' entrepreneurial personality are the psychological, the sociological and the economic ones.

Regarding the psychological approach, Chell (2008) understanding is that the personality comes from an "internal" structure, and it is understood as specific personality traits that help to measure personal attributes that typify the entrepreneurial features. The present study seeks to contribute to the mapping of such psychological features using the entrepreneurial self-efficacy as a construct, with its personality traits bias, which affects the particular domain of creating a new business task.

From the sociological approach, Chell (2008) postulates that the entrepreneur's behavior model is influenced by social rules, norms and responsibilities that together give a sense of legitimacy to the entrepreneurial personality. The author mentions that behavior is conditioned to socioeconomic system levels governed by rules and economic policies. In this research, in order to identify the entrepreneur sociological features, the entrepreneurial intention is used as a construct of study that deals with the individual's behavior from a set of social, cultural and economic variables that influence their willingness to create a business.

Finally, considering Chell (2008) economic approach, entrepreneurs assume features geared to the behavior model influenced by social rules, norms, and responsibilities that may be imposed by public policies. These individuals' behavior is driven by the socioeconomic system that, once guided by innovative features, can promote the development of an entrepreneurial personality. On this assumption, the study seeks to relate the entrepreneurial characteristics with the effective capacity of innovation that entrepreneurs manifest. 
Another aspect related to the characteristics and the environment in which entrepreneurs are inserted is associated with the small number of researches linking the entrepreneur and the technological environment. For Shane \& Venkataraman (2003), the available literature on the creation process of incubated and technology-based companies was incomplete, leaving much to discover and understand about the creation process particularities of this type of business. Salvador (2011) points out that incubator enterprises and technology parks play a major role in the performance of the spin-offs and also in safeguarding the development potential of the incubated companies, conducting courses, and seminars, providing information and promoting the creation of products and services.

In this light, the objective of this research is to analyze the influence of some entrepreneur personality characteristics, named entrepreneurial self-efficacy, entrepreneurial intention and innovation capacity on the organizational performance of incubated companies in Santa Catarina.

\section{Theoretical Framework}

In this study, the entrepreneurial characteristics addressed: entrepreneurial self-efficacy, entrepreneurial intention, and innovation capacity are associated with disciplinary approaches adopted by Chell (2008). These constructs, which underlie the assumptions of this research, will be further conceptualized, as well as the relations among them.

Empirical studies have examined the influence of entrepreneurial self-efficacy on entrepreneurial intention in different contexts. De Noble et al. (1999) conducted a survey with 272 undergraduate students, and their findings indicate that the measurement scale proposed in the study revealed that self-efficacy correlated positively and significantly with entrepreneurial intention, as well as the current availability of students in creating or starting their own businesses.

Salanova et al. (2001) point out that the positive self-efficacy is related to the persistence, dedication and satisfaction related to the actions performed. Zhao et al. (2005) suggest that individuals who choose to become entrepreneurs have high entrepreneurial self-efficacy. Thus, the individual's belief in achieving success when launching an enterprise, according to McGee et al. (2009), is an important variable, once it is a strong predictor of entrepreneurial intentions. Santos (2008) points out that individual, social and informational background factors influence behavioral, normative and control beliefs, which, in turn, define the attitudes of an individual that lead to the formation of entrepreneurial intention and behavior.

Kickul et al. (2009) highlight that it is necessary to understand which factors can influence the intentions of those who may become future entrepreneurs. These factors vary and consist of a combination of personal attributes, traits, experience and context. On the contextual aspects, studies show that environmental influences and support have an impact on entrepreneurial intentions (Shepherd \& Krueger, 2002). The research held by Zhao et al. (2005) directed to individual domains showed that characteristics such as self-efficacy and propensity for risktaking, along with the competencies and skills developed, influence entrepreneurial intentions.

De Noble et al. (1999) understand self-efficacy as a bridge concept that could explain the initial effort of an entrepreneur to create and develop new business. Krueger et al. (2000) found a positive relation between 
perceived self-efficacy and entrepreneurial intention, where the developed self-efficacy may explain the cognitive characteristics of entrepreneurs.

Researches also claim the relationship between self-efficacy and intention, that is, individuals with high selfefficacy tend to have higher entrepreneurial intentions (Chen et al., 1998; De Noble et al., 1999; Jung et al., 2001; Segal et al., 2002). The results of these studies substantiate the hypothesis that follows: $\boldsymbol{H 1}$ - Entrepreneurial selfefficacy influences positively and significantly the entrepreneurial intention.

Regarding innovation capacity, Jain \& Ali (2013) argue that entrepreneurship is positively associated with the increasing technological progress. In addition, the opportunity of innovating is one of the most significant reasons to start a new business. Carland \& Carland (2009) address innovation as the soul of entrepreneurship, i.e., as an economic engine and the vital essence of the real entrepreneurship.

Entrepreneurial self-efficacy and innovation capacity are approached in the literature as a characteristic that permeates the entrepreneurs' personality and abilities. Santos et al. (2010) conducted a study in order to analyze undergraduate students' attitudes toward entrepreneurship, systematizing and operationalizing the individual features that can be distinguished relatively from entrepreneurial capacity, the later on being understood as the set of psychological characteristics of entrepreneurs.

According to the findings of that research, these features are grouped into four dimensions: entrepreneurial motivations (desire for independence and economic motivation), psychological competence (innovation capacity, emotional intelligence and resilience), social competence (communication capability and persuasion, capacity to develop a social network), and management competence (vision, ability to mobilize resources, leadership capacity and entrepreneurial self-efficacy). Results show different levels of entrepreneurial capacity with statistically significant differences in mean values of the sub-dimensions of desire for independence, economic motivation, innovation and communication capacity, ability to mobilize resources, leadership capacity and entrepreneurial self-efficacy. Social Sciences students present a higher entrepreneurship index. In this context, it is postulated the hypothesis that follows: $\mathbf{H 2}$ - The self-entrepreneurial efficacy influences positively and significantly the innovation capacity.

The innovation capacity can be defined as the force or proficiency of a set of organizational practices for the development of new products and/or processes (Peng et al., 2008). Some empirical studies have focused on understanding the factors that contribute to this construct development in different perspectives. Thus, Chow \& Gong (2010) studied the Human Resources (HR) practices based on knowledge retention to fully understand the role of human resource management in technology-intensive sectors in China. The findings of that research show a direct link between the HR types and the company's performance, in addition to the significant effect of innovation capacity in the analyzed companies' performance, and, yet, that the innovation capacity shows significant impact on the results related to technology-intensive knowledge in these Chinese companies. 
In a research of Kim \& Lee (2012), the results revealed that organizational innovation capacity showed a positive and significant effect on organizational performance and that companies with higher levels of innovation capacity tend to have better financial performance, with sales growth, profitability and market share.

Similarly, Dadfar et al. (2013) research indicates the identification of a positive relationship between the organizational innovation capacity and the development of products, as well as the financial performance of the Iranian pharmaceutical industries. That is, the empirical analysis showed a positive relation between innovation capacity, technology, product range, and performance. The result endorses what has been found in studies with entrepreneurs, that the resources and the innovation capacity have a positive influence on companies' performance (Rauch et al., 2004; Jain \& Ali, 2013).

Performance can be treated as a dependent factor of innovation capacity, and it is well connected in innovative organizations when they exhibit a consistent innovative behavior over time. Valladares et al. (2014) mention that understanding the performance relation with the innovation capacity compared to its competitors is relevant in empirical research for it helps to reduce the industry effect. In this sense, we propose the following hypothesis: H3 - The innovation capacity influences positively and significantly organizational performance.

The entrepreneurial intention is materialized by the initiative of individuals in creating or opening their own business. Koe et al. (2012) emphasize that understanding the factors that predict the intention is critical in order to understand them, being the entrepreneurial behavior the result of entrepreneurial intention.

Researches on this field seek to understand the entrepreneurial intention, beyond the entrepreneurial behavior, and focus on the environment in which entrepreneurs are inserted. In this context, besides the development of the entrepreneurial profile focusing on the individual, support mechanisms for start-up companies are made available to entrepreneurs who want to open their own business, i.e., to those who have entrepreneurial intention. These mechanisms range from credit lines, business incubators, technology parks, consultancies, subsidized advisory services, and events for the promotion of business networks that seek to foster entrepreneurship (Schmidt \& Bohnenberger, 2009).

In line with this thought, there are empirical studies that have begun to relate the constructs of entrepreneurial intention and organizational performance, such as the study by Schmidt \& Bohnenberger (2009). The authors aimed to construct and validate a model that allows verifying the relation between the entrepreneurial profile of students of higher education institutions and the organizational performance of the companies managed by them. The findings reveal that the entrepreneur profile is a multidimensional construct composed of six characteristics and that only the self-realization proved to be related to the organizational performance.

Torres \& Watson (2012) worked on the constructs of entrepreneurial self-efficacy, entrepreneurial intention, and performance in a sample of small Mexican companies. They found out that owners and managers associate their tasks according to their perception of the degree of difficulty and complexity and not to the specific knowledge in areas such as marketing and management. Besides, they ascertained that the expansion (one of the 
three elements of entrepreneurial self-efficacy), according to the model used, which involves heavier work and less knowledge, positively explains the performance, but negatively affects the entrepreneurial intention.

Their research data also showed that high performance requires higher levels of belief from the owner or manager about their ability to perform their tasks, and that the proactive involvement represents this capacity that should be considered in the management skills assessment. Regarding the owners' or managers' entrepreneurial intention, it is defined as their willingness to allocate resources for the business growth and developments., The higher their level of conviction about their ability to perform difficult or complex tasks is, the lower is their entrepreneurial intention.

To the extent that this effect appears to be contrary to common sense, it seems to be in line with the findings of Arenius \& Minniti (2005) who suggest that decisions to be undertaken are often based on subjective and biased perceptions. Thus, organizational performance requires hard work, but as for the entrepreneurial intention, it mostly comes from people who are overconfident and willing to exploit an opportunity. In this context, the following hypothesis is postulated: H4 - The entrepreneurial intention relates to organizational performance.

\section{Methods}

This study of descriptive type and quantitative approach aimed to analyze the influence of some entrepreneurs' personality characteristics, which are entrepreneurial self-efficacy, entrepreneurial intention, and innovation capacity on the organizational performance of incubated companies in Santa Catarina, Brazil. For this purpose, data were collected through self-administered questionnaires, applied during the first semester of 2015 with 68 firms that were willing to answer the survey instrument.

According to the mapping carried out in the second semester of 2014, the population was composed of 339 companies hosted in the 25 incubator companies of Santa Catarina. The method adopted for choosing the participants in this survey research (Babbie, 2003) was accessibility, what means that only the companies that answered the questionnaire composed the sample. It is noteworthy that the minimum sample size was calculated from the G*Power software, suitable for studies that adopt the structural equation modeling (SEM) guided in partial least squares (PLS).

The measurement scale used for the entrepreneurial self-efficacy construct was the one created by De Noble et al. (1999) and adapted to Portuguese language by Lizote et al. (2013). It is composed of 23 items with the seven-point Likert-type format, ranging from "completely incapable" (1) to "fully capable" (7). This scale includes six dimensions: development of new products and market opportunities (DN), innovative environment building (AI), main business objective definition (ON), development of key human resources for the company (HR), starting relations with investors (IR), and dealing with unexpected changes (MI).

For the entrepreneurial intention construct, the research joins the Theory of Planned Behavior (TCP) proposed by Ajzen (1991) and uses the scale proposed in the study by Dakoumi \& Abdelwahed (2014), with the necessary adaptations to the object of this study. The scale used is composed of three dimensions: attitude toward behavior (ARC), subjective norms (NS), and perceived behavior control (CCP). And its measure is taken by means of 
18 statements to be answered on a seven-point Likert scale of agreement, ranging from "strongly disagree" (1) to "strongly agree" (7).

Regarding the innovation capacity construct, it was based on the conceptual model and the scale of Liao et al. (2007). After proceeding to specific adaptations for the work with incubated companies, the instrument ended up being composed of 18 affirmatives evenly distributed among the dimensions: products innovation, processes innovation, and management innovation, to be answered in a seven-point Likert scale of agreement, ranging from "strongly disagree" (1) to "strongly agree" (7).

Finally, for the organizational performance construct, it was used a questionnaire employed by Lizote et al. (2013), which is based on the work of Gupta \& Govindarajan (1984). The data corresponding to the performance are collected from five descriptors to be evaluated by the respondents with a seven-point Likert scale of satisfaction, ranging from "completely dissatisfied" (1) to "fully satisfied" (7).

For the quantitative data analysis, it was used the structural equation modeling with the support of the method of partial least squares (SEM-PLS). The processing is performed with SmartPLS ${ }^{\circledR}$ software (Ringle et al., 2005) from the correlation matrix and thus circumvents the lack of data normality (Chin, 1998; Hair et al., 2014).

Further, criteria for validity and reliability and adjustments of models were established. For reliability, internal consistency indicators were observed, and it was measured by Cronbach's alpha, which, because of the values between 0.6 and 0.7 , allows to assume that all indicators are equally reliable. Indicators of composite reliability were also observed, for being a conservative measure and less sensitive to small quantities of indicators it requires values between 0.7 and 0.9. Then it was observed the model of explanation with the support of determination coefficient $\left(\mathrm{R}^{2}\right)$ and other adjustment quality indicators.

For convergent validity, the average variance extracted (AVE) was observed, indicating the extent that the model variables are explained while they correlate with other measures of the same construct and, when taken together, seek to explain the model. In this situation it is verified the factor loadings for each item so that it is above 0,708 since lower values do not allow the general explanation of the construct to reach $50 \%$.

In the discriminate validity, which assesses whether the constructs are different, that is, if what is actually intended to measure for each construct is achieved, we usedit was used the Fornel-Lacker criterion. Its calculation implies obtaining the square root of the AVE of the construct, and it must be superior to any of its correlation with other constructs of the model. As for adjusting the model, it was observed the significance of the relations between the variables with the bootstrapping technique using the student's t-test with acceptance criteria at $10 \%$ ( $t \geq 1.67, p$ $\leq 0.10$ ) in compliance with the Stone-Geisser indicators for predictive validity (Q2), and Cohen indicator (f2), which observes the effect size of the construct in the model (Hair et al., 2014).

The $\mathrm{Q}^{2}$ must be greater than zero, and $\mathrm{f}^{2}$ has as parameters $0.02,0.15$ and 0.35 for indicators of low, medium and high effect, respectively. It was also considered the adequacy index of the model goodness of fit (GoF) obtained by the geometric mean between the medium $\mathrm{R}^{2}$ (structural model adjustment), and the average AVE. This 
indicator is considered appropriate in the applied social sciences when above 0.36 (Hair et al., 2014). Figure 1 shows the summary of the structural model adjustments at SmartPLS.

\section{Figure 1}

Summary of the structural model adjustments SmartPLS

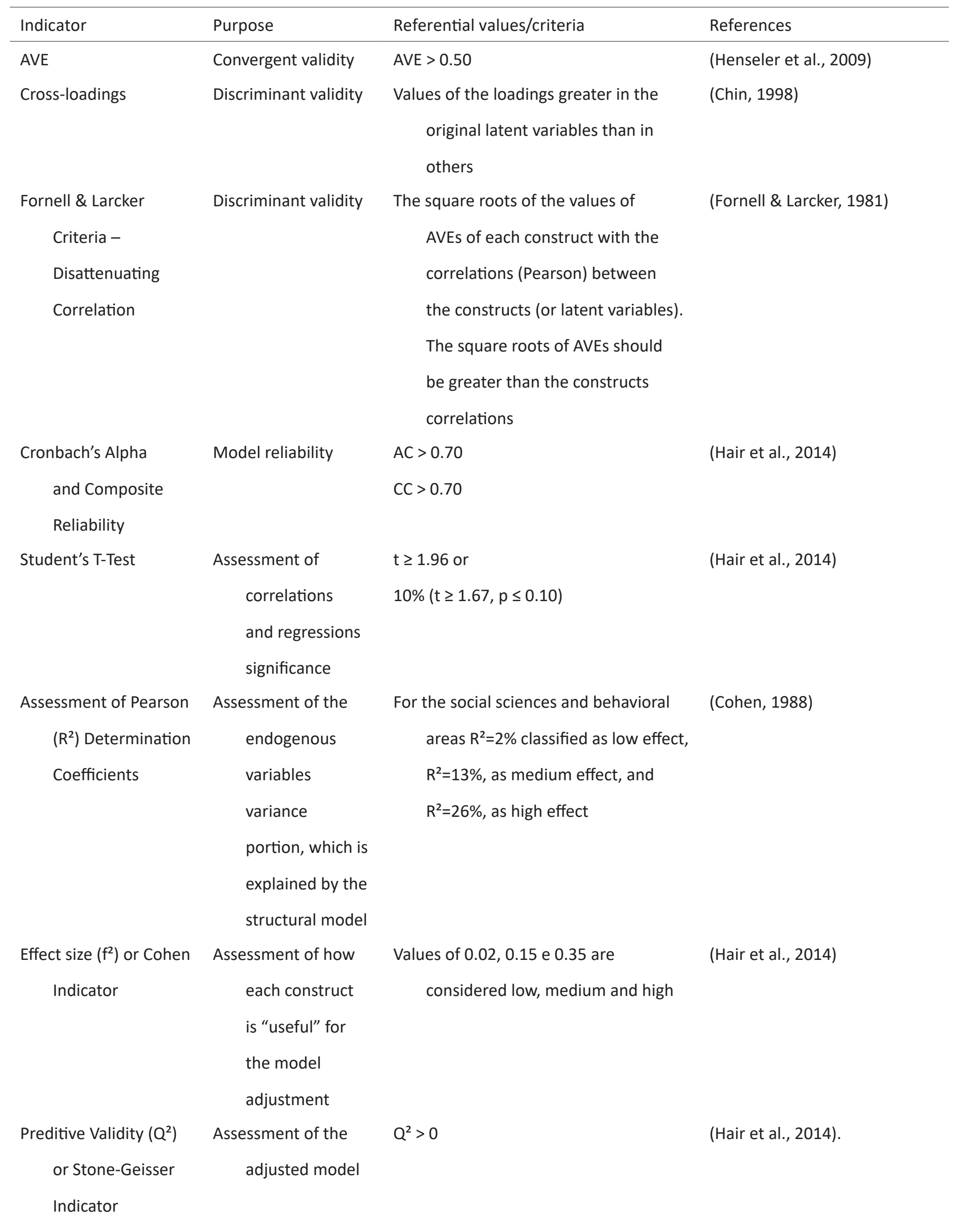




\begin{tabular}{llll}
\hline Indicator & Purpose & Referential values/criteria & References \\
\hline Goodnessof Fit (GoF) & It is global quality & GoF>0,36 & (Tenenhaus et al., 2005; \\
& score of the & & Wetzels et al., 2009) \\
adjusted model. & & Values interpretation in the light of the & (Hair et al., 2014). \\
Path coefficient $(\Gamma)$ & Causal relations & assessment & theory
\end{tabular}

Note. Adapted from Ringle et al. (2014, p. 72)

\section{Results}

In this section, the managers' profiles of the surveyed incubated companies are presented. After that, it is shown the structural equation modeling with the one that analyses the relationship between the constructs covered in the study. To determine the profile of the people who answered the survey instrument, we attempted to analyze gender and average age as well as their education level and the position they hold in the company.

Regarding the gender of the managers, it was found that $87 \%$ are male and $13 \%$ are female. The average age of respondents is 43 , with a standard deviation of 8.9 years. Further, Table 1 shows their schooling formation

\section{Table 1}

\section{Education level of respondents}

\begin{tabular}{lc}
\hline Education Level & Respondents \\
\hline High School & 1 \\
Technical School & 5 \\
Graduation - complete & 25 \\
Graduation - incomplete & 6 \\
Post-Graduation - Lato sensu - complete & 15 \\
Post-Graduation - Lato sensu - incomplete & 3 \\
Post-Graduation - Master degree - complete & 9 \\
Post-Graduation - Master degree - incomplete & 2 \\
Post-Graduation - Doctorate degree & 2 \\
\hline Total & 68 \\
\hline
\end{tabular}

In Table 2, it is observed the prevalence of respondents with college degrees (37\%), followed by people with complete (22\%) and incomplete (4\%) lato sensu post-graduate degrees. Table 2 depicts the position or function occupied by the respondents in the incubated companies analyzed.

\section{Table 2}

Position or function occupied in the company

\begin{tabular}{lcc}
\hline Position or function occupied & No. resp. & $(\%)$ \\
\hline Administrator & 7 & 10 \\
Administrative assistant & 2 & 3 \\
Systems Analyst & 1 & 1 \\
CEO & 4 & 6
\end{tabular}




\begin{tabular}{lcc}
\hline Position or function occupied & No. resp. & (\%) \\
\hline Director & 21 & 31 \\
Administrative director & 2 & 3 \\
Commercial director & 7 & 10 \\
Financial director & 1 & 1 \\
Executive director & 1 & 1 \\
Technical director & 5 & 7 \\
Projects director & 2 & 3 \\
Purchasing director & 1 & 1 \\
Engineer & 1 & 1 \\
Co-owner & 13 & 19 \\
\hline Total & 68 & 100 \\
\hline
\end{tabular}

In general, it is clear that respondents are the managers of the analyzed companies, once the predominant functions are directors (31\%) and co-owners (19\%). Further, it is discussed the structural equation modeling based on SmartPLS to demonstrate the relation between the constructs through the path coefficients indicators shown in Table 3.

\section{Table 3}

Path Coefficients Indicators $(\Gamma)$ and t-test

\begin{tabular}{|c|c|c|c|c|c|c|c|}
\hline $\mathrm{H}$ & Relation & (Г) & $\begin{array}{l}\text { AVE samples } 200 \\
\text { subsamples }\end{array}$ & Standard deviation & t- test & Pp-value & Result \\
\hline $\mathrm{H}_{1}$ & $\begin{array}{l}\text { Entrepreneurial } \\
\text { Self-efficacy => } \\
\text { Entrepreneurial } \\
\text { Intention }\end{array}$ & 0.665 & 0.663 & 00.086 & 77.742 & 00.000 & Confirmed \\
\hline $\mathrm{H}_{2}$ & $\begin{array}{l}\text { Entrepreneurial } \\
\qquad \begin{array}{l}\text { Self-efficacy }=> \\
\text { Innovation Capacity }\end{array}\end{array}$ & 0.625 & 0.635 & 00.140 & 44.472 & 00.000 & Confirmed \\
\hline $\mathrm{H}_{3}$ & $\begin{array}{c}\text { Innovation Capacity => } \\
\text { Performance }\end{array}$ & 0.291 & 0.325 & 00.130 & 22.249 & 00.028 & Confirmed \\
\hline $\mathrm{H}_{4}$ & $\begin{array}{l}\text { Entrepreneurial } \\
\qquad \begin{array}{l}\text { Intention => } \\
\text { Performance }\end{array}\end{array}$ & 0.186 & 0.186 & 00.100 & 11.730 & 00.088 & Confirmed \\
\hline
\end{tabular}

According to Table 4, the general structural model is adjusted, since it has positive and significant relations ( $p<0.10$ and $t>1.67)$ among all constructs identified by bootstrap resampling method.

It is also possible to verify the significance of the relationship between Entrepreneurial Self-efficacy and Innovation Capacity $\left(\mathbf{H}_{2}, \Gamma=0.625, t_{(67)}=4.472\right.$, p-value $\left.<0.001\right)$, Entrepreneurial Self-efficacy and Entrepreneurial Intention $\left(\mathbf{H}_{1}, \Gamma=0.665, \mathrm{t}_{(67)}=7.742, \mathrm{p}\right.$-value $\left.<0.001\right)$, Innovation Capacity and Performance $\left(\mathbf{H}_{3}, \Gamma=0.291, \mathrm{t}_{(67)}\right.$ 
$=2.249, \mathrm{p}$-value $=0.028)$ and Entrepreneurial Intention and Performance $\left(\mathbf{H}_{4}, \Gamma=0.186, \mathrm{t}_{(67)}=1.730, \mathrm{p}\right.$-value $=$ 0.088). It is worth highlighting the strong relation between the associations Entrepreneurial Self-efficacy and Entrepreneurial Intention, with $\mathrm{t}_{(67)}=7.742$, and between Entrepreneurial Self-efficacy and Innovation Capacity, with $t_{(67)}=4.472$.

Predictive Validity $\left(\mathrm{Q}^{2}\right)$, also known as the Stone-Geiser or accuracy indicator, according to Hair et al. (2014) and Silva (2015), evaluates the accuracy of the fit model. Ringle et al. (2014, p. 15) point out that the $Q^{2}$ "evaluates how the model is close to what it is expected of it, or the quality of the prediction model or accuracy of the adjusted model." It is noteworthy that a perfect model would be $Q^{2}=1$, being interpreted as a model that reflects the reality without errors. For the interpretation of the values Hair et al. (2014) and Silva (2015) indicate that the predictive validity must present values greater than zero.

Regarding the Effect Size $\left(f^{2}\right)$, also known as Cohen Indicator, according to Hair et al. (2014) and Silva (2015), is an indicator obtained by the inclusion and exclusion of endogenous constructs in the model. This way it is possible to assess how useful for the conceptual model fitting each construct is. For the interpretation of the coefficient, values close to 0.02 are considered for little use, values close to 0.15 , for moderate use, and values close to 0.35 for useful ones. Table 4 presents accuracy indicators $\left(\mathrm{Q}^{2}\right)$ and useful indicators for the model construction $\left(f^{2}\right)$.

\section{Table 4}

Accuracy indicator and usefulness to model construction

\begin{tabular}{lcc}
\hline Variables & $\mathrm{Q}^{2}$ & $\mathrm{f}^{2}$ \\
\hline Entrepreneurial self-efficacy & - & 0.501 \\
(DN) New products development & 0.575 & - \\
(MI) Unexpected changes & 0.575 & - \\
(ON) Business objective & 0.693 & - \\
(RH) Human Resources & 0.597 & - \\
(RI) Relation with investors & 0.483 & - \\
(AI) Innovative environment & 0.434 & - \\
Performance & 0.107 & - \\
Entrepreneurial Intention & 0.158 & 0.378 \\
(ARC) Attitude toward behavior & 0.563 & - \\
(CCP) Perceived behavior control & 0.488 & - \\
(IE) Entrepreneurial Intention_VL & 0.267 & - \\
(NS) Subjective norms & 0.435 & - \\
Innovation Capacity & 0.199 & 0.505 \\
(IP) Processes innovation & 0.658 & - \\
(IS) Products innovation & 0.457 & - \\
(IG) Management Innovation & 0.531 & - \\
\hline & & \\
\hline
\end{tabular}


Based on Table 5, it is found out, considering the predictive validity $\left(Q^{2}\right)$, that the model showed accuracy, since the variables analyzed showed very high values. It is noteworthy analyzing that the variable "Business Purpose", with $\mathrm{Q}^{2}$ of 0.693 , was the most explained item by the structural model, followed by the variable "Processes Innovation", with $\mathrm{Q}^{2}$ of 0.658 . It is also highlighted that the less explained variable in the model was "Performance" with $\mathrm{Q}^{2}=0.107$

Regarding the Effect Size $\left(\mathrm{f}^{2}\right)$, the general structural model presented useful constructs for its explanation, since the values were predominantly higher than 0.30 . It is worth mentioning that the variable "Performance" has no value $\mathrm{f}^{2}$, once the structural model presents no output predictor, only two input ones, as in Figure 1 . However, it is noted that in Table 5 the construct "Innovation capacity" was the most important to explain the structural model, since it achieved an effect size of 0.505 , followed by the constructs "Entrepreneurial Self-efficacy", with $\mathrm{f}^{2}$ of 0.501 , and "Entrepreneurial Intention", with $\mathrm{f}^{2}$ of 0.378.

Figure 2 shows the research general structural model, and Table 4 presents the relations among the 1st and 2nd order variables, which also had positive and significant relations.

Table 5

Relations among $1^{\text {st }}$ and $2^{\text {nd }}$ order variables of the structural model

\begin{tabular}{|c|c|c|c|c|c|}
\hline Relations & (Г) & $\begin{array}{l}\text { Average } 200 \\
\text { subsamples }\end{array}$ & $\begin{array}{l}\text { Standard } \\
\text { Deviation }\end{array}$ & t Student & p-value \\
\hline Entrepreneurial self-efficacy -> New products development & 0,868 & 0,866 & 0,039 & 22,516 & $p<0,001$ \\
\hline Entrepreneurial self-efficacy -> Unexpected changes & 0,836 & 0,831 & 0,057 & 14,544 & $p<0,001$ \\
\hline Entrepreneurial self-efficacy -> Business objective & 0,929 & 0,927 & 0,021 & 45,345 & $p<0,001$ \\
\hline Entrepreneurial self-efficacy -> Human resources & 0,860 & 0,862 & 0,033 & 26,475 & $p<0,001$ \\
\hline Entrepreneurial self-efficacy -> Relations with investors & 0,752 & 0,751 & 0,053 & 14,193 & $p<0,001$ \\
\hline Entrepreneurial self-efficacy -> Being innovative & 0,717 & 0,695 & 0,110 & 6,543 & $p>0,001$ \\
\hline Innovation capacity -> Processes innovation & 0,950 & 0,950 & 0,015 & 64,247 & $p<0,001$ \\
\hline Innovation capacity -> Products innovation & 0,849 & 0,848 & 0,041 & 20,947 & $p<0,001$ \\
\hline Innovation capacity -> Management innovation & 0,885 & 0,884 & 0,044 & 19,916 & $p<0,001$ \\
\hline Entrepreneurial intention -> Attitude towards behavior & 0,846 & 0,840 & 0,058 & 14,676 & $p<0,001$ \\
\hline Entrepreneurial intention -> Perceived behavior control & 0,864 & 0,856 & 0,055 & 15,698 & $\mathrm{p}<0,001$ \\
\hline Entrepreneurial intention -> Entrepreneurial intention_VL & 0,632 & 0,601 & 0,157 & 4,025 & $p<0,001$ \\
\hline Entrepreneurial intention -> Subjective norms & 0,716 & 0,701 & 0,116 & 6,164 & $p<0,001$ \\
\hline
\end{tabular}

In Table 5, accurate indicators of the adjusted model or predictive validity $\left(\mathrm{Q}^{2}\right)$ and effect size or utility for the model construction $\left(\mathrm{f}^{2}\right)$ were satisfactory, in addition to the $\mathrm{p}$-value that showed less than 0.05 in all analyzed relations. It is noteworthy that the relationship with greater explanatory power in the model was Innovation Capacity and Process Innovation, with $t_{(67)}=64.247$, followed by the relation Entrepreneurial Self-efficacy and Business Objective, with $\mathrm{t}_{(67)}=45.345$. In the third position comes the relation between Entrepreneurial Self-efficacy and Human Resources, with $\mathrm{t}_{(67)}=26.475$. In contrast, the relationship with less explanatory power in the model was Entrepreneurial Intention and Entrepreneurial Intention_VL, with $\mathrm{t}_{(67)}=4.025$. 
Figure 2 shows all indicators of the final adjusted structural model and can summarize the results obtained through the structural equation modeling analysis.

Figure 2

Indicators of the final adjusted structural model

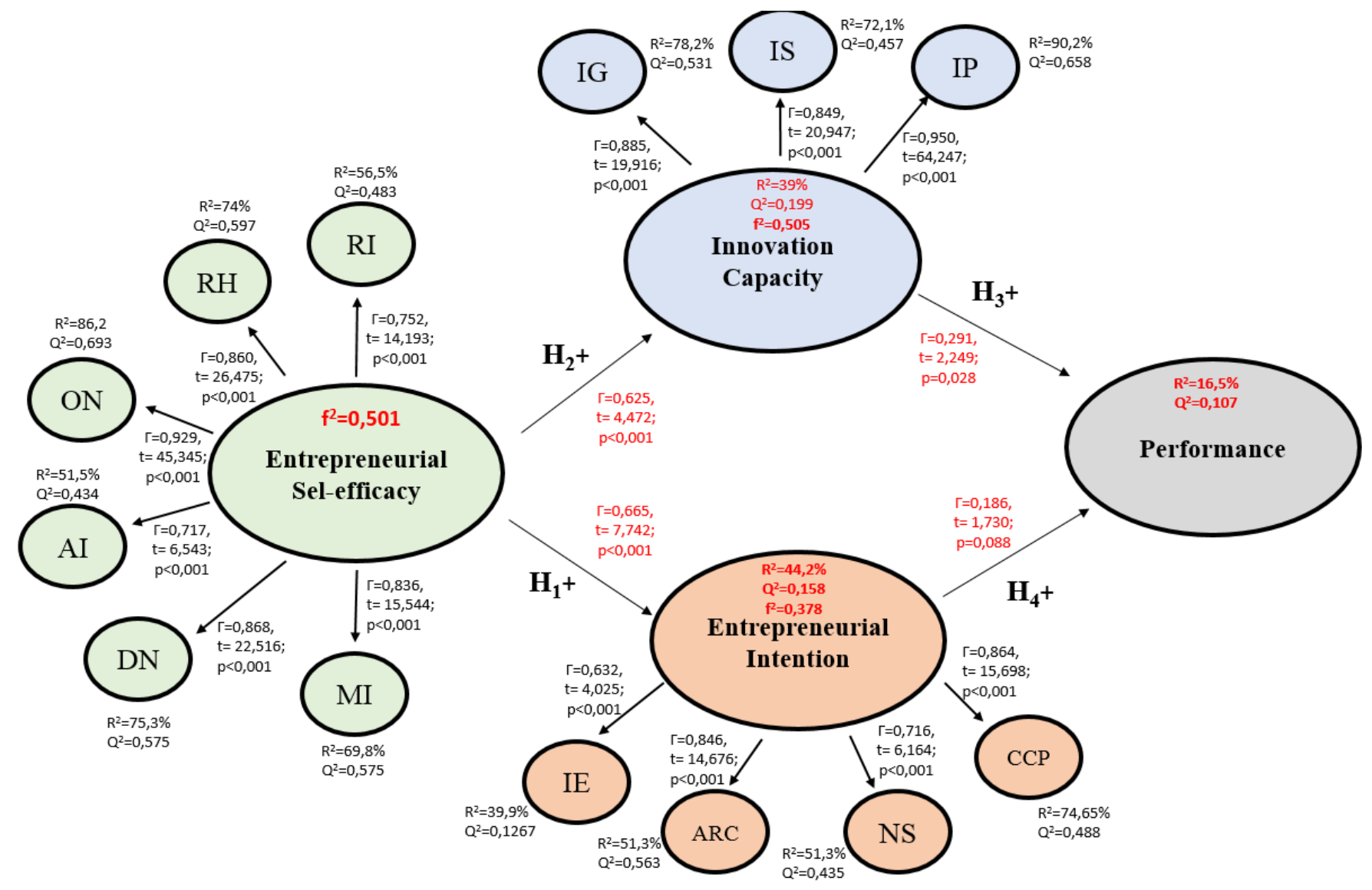

Final Remarks

The objectives proposed for the study were achieved, once it was possible to analyze the influence of some entrepreneurs' personality characteristics on organizational performance of the incubated companies in Santa Catarina, Brazil. The use of structural equation modeling applying the method of partial least squares (SEM-PLS) allowed to evaluate the associations of entrepreneurial self-efficacy with the entrepreneurial intent and the capacity for innovation, and in both cases, it is positive and very significant $(p<0.001)$. Thus, the first two postulated hypotheses were corroborated.

The linking of the entrepreneurial intention and innovation capacity with organizational performance can also be measured with the SEM-PLS.

With the modeling, it was possible to verify that those constructs have a positive and significant relation with the performance, which confirms the conjectured hypotheses. However, its significance was lower: $5 \%$ for entrepreneurial intent $(p=0.028)$ and $10 \%$ for innovation capacity $(p=0.088)$.

The results of this study adhere to the model of Chell (2008), which postulates that the psychological, sociological and economic components must be taken into consideration when the entrepreneurial personality is at issue. Therefore it is concluded that the study of entrepreneurs' actions should be carried out from a multidimensional perspective. 
It should be noted the importance of replicating this kind of research under other conditions, for example with graduated companies. It is also important to consider the possibility of other aspects interfering in the evaluated relations, as the entrepreneurs' cognitive style. Undoubtedly, the studies carried out further besides expanding the empirical results framework may work as basis to new theoretical perspectives on the entrepreneurship area. 


\section{References}

Ajzen, I. (1991), The theory of planned behavior. Organizational Behavior and Human Decision Processes, vol. 50 (2), pp. 179-211.

Arenius, P. \& Minniti, M. (2005), Perceptual variables and nascent entrepreneurship. Small Business Economics, vol. 24 (4), pp. 233-247.

Babbie, E. (2003), Métodos de pesquisa de survey. UFMG, Belo Horizonte.

Baker, T. \& Nelson, R. E. (2005), Creating something from nothing: resource construction through entrepreneurial bricolage. Academy Science Quarterly, vol. 50, pp. 329-366.

Carland, J. A. \& Carland, J. (2009), Innovation: the soul of entrepreneurship. Small Business Institute, 33(1), winter.

Chell, E. (2008), The entrepreneurial personality: a social construction. Taylor \& Francis, New York

Chen, C. C., Greene, P. G. \& Crick, A. (1998), Self-efficacy distinguish entrepreneurs from managers? Journal of Business Venturing, vol. 13, pp. 295-316.

Chin, W. W. (1998), The partial least squares approach for structural equation modeling. In Marcoulides, G. A. (Ed.), Modern methods for business research. Lawrence Erlbaum Associates, London, pp. 205-236.

Chow, I. H. S. \& Gong, Y. (2010), The linkage of HRM and knowledge-related performance in China's technologyintensive industries. The International Journal of Human Resource Management, vol. 21 (8), pp. 1289-1306.

Cohen, J. (1988), Statistical power analysis for the behavioral sciences. 2nd ed. New York: Psychology Press.

Dadfar, H., Dahlgaard, J. J., Brege, S. \& Alamirhoor, A. (2013), Linkage between organizational innovation capability, product platform development and performance. Total Quality Management, vol. 24 (7), pp. 819-834.

Dakoumi, A. H. \& Abdelwahed, Y. (2014), Is entrepreneurship for you? Effects of storytelling on Entrepreneurial Intention. International Journal of Business and Management, vol. 9 (9).

De Noble, A., Jung, D. \& Ehrlich, S. (1999), Entrepreneurial self-efficacy: the development of a measure and its relationship to entrepreneurial actions. Trabajo presentado en el Frontiers of Entrepreneurship Research.

Fornell, C., \& Larcker, D. F. (1981), Evaluating structural equation models with unobservable variables and measurement error. Journal of Marketing Research, vol. 18, (1), pp.39-50.

Gupta, A. \& Govindarajan, V. (1984), Business unit strategy, managerial characteristics, and business unit effectiveness at strategy implementation. Academy of Management Journal, vol. 27 (1), pp. 25-41.

Hair, J. F., Hult, G. T. M., Ringle, C. M. \& Sarstedt, M. (2014), A primer on Partial Least Squares Structural Equation Modeling (PLS-SEM). SAGE, Los Angeles.

Henseler, J., Ringle, C. M., \& Sinkovics, R. R. (2009), The use of partial least squares path modeling in international marketing. Advances in International Marketing, vol. 20, pp.277-319.

Jain, R. \& Ali, S. W. (2013), A review of facilitators, barriers and gateways to entrepreneurship: directions for future research. South Asian Journal of Management, vol. 20 (3), pp. 122-163. 
Kickul, J., Gundry, L. K., Barbosa, S. D. \& Whitcanack, L. (2009), Intuition versus analysis? Testing differential models of cognitive style on entrepreneurial self-efficacy and the new venture creation process. Theory \& Practice, vol. 33 (2), pp. $439-453$.

Kim, T. \& Lee, G. (2012), A modified and extended triands model for the enablers-process-outcomes relationship in the employees knowledge sharing. Service Industries Journal, vol. 32 (13), pp. 2059-2090.

Koe, W., Sa'ari, J. R., Majid, L. A. \& Ismail, K (2012), Determinants of entrepreneurial intention among millennial generation. Procedia - Social and Behavioral Sciences, vol. 40, pp. 197-208.

Krueger Jr, N. F., Reilly, M. D. \& Carsrud, A. L. (2000), Competing models of entrepreneurial intentions. Journal of Business Venturing, vol. 15 (5-6), pp. 411-432.

Lenzi, F. C. (2008), Os empreendedores corporativos nas empresas de grande porte: um estudo da associação entre tipos psicológicos e competências empreendedoras [Doctoral thesis, Universidade de São Paulo].

Liao, S., Fei, W. \& Chen, C. (2007), Knowledge sharing, absorptive capacity, and Innovation capacity: an empirical study of Taiwan's knowledge-intensive industries. Journal of Information Science, vol. 33.

Lizote, S. A., Verdinelli, M. A. \& Silveira, A. (2013), Relação entre autoeficácia e competências empreendedoras de gerentes com o desempenho das empresas instaladas em incubadoras tecnológicas de Santa Catarina, Brasil. Proceedings of the Lation-Iberoamericana de Gestão de Tecnologia.

Mcgee, J. E., Peterson, M., Mueller, S. L. \& Sequeira, J. M. (2009), Entrepreneurial self-efficacy: refining the measure. Entrepreneurship: Theory \& Practice, vol. 33 (4), pp. 965-96.

Peng, D. X., Schroeder, R. G. \& Shah, R. (2008), Linking routines to operations capabilities: a new perspective. Journal of Operations Management, vol. 26 (6), pp. 730-748.

Rauch, A., Wiklund, J., Lumpkin, G. T., \& Frese, M. (2004), Entrepreneurial orientation and business performance: cumulative empirical evidence. Proceeding of the Frontiers of Entrepreneurship Research, 2004.

Ringle, C. M., Silva, D. \& Bido, D. (2014), Modelagem de equações estruturais com utilização do SmartPLS. Brazilian Journal of Marketing, vol. 13 (2), pp. 56-73.

Ringle, C. M., Wende, S. \& Will, A. (2010), Finite mixture partial least squares analysis: methodology and numerical examples. Handbook of partial least squares. Berlin: Springer Berlin Heidelberg, pp. 195-218.

Salanova, M., Grau, R., Llorens, S. \& Schaufeli, W. B. (2001), Exposición a las tecnologías de la información, burnout y engagement: el rol modulador de la autoeficacia profesional. Psicología Social Aplicada, vol. 11 (1), pp. 69-89.

Salvador, E. (2011), Are science parks and incubators good "brand names" for spin-offs? The case study of Turin. Journal Technologic Transfer, vol. 36, pp. 203-232.

Santos, P. C. F. (2008), Uma escala para identificar potencial empreendedora [Doctoral thesis, Universidade Federal de Santa Catarina].

Santos, S. C., Caetano, A. \& Curral, L. (2010), Atitude dos estudantes universitários face ao empreendedorismo como identificar o potencial empreendedor? Revista Portuguesa e Brasileira de Gestão, vol. 9 (4), pp. 2-14. 
Schmidt, S. \& Bohnenberger, M. C. (2009), Perfil empreendedor e desempenho organizacional. Revista de Administração Contemporânea, vol. 13 (3), pp. 450-467.

Segal, G., Borgia, D. \& Schoenfeld, J. (2002), Using social cognitive career theory to predict self-employment goals. New England Journal of Entrepreneurship, vol. 5 (2), pp. 47-56.

Silva, D. (2015). Modelagem de equações estruturais usando o SmartPLS. Classes notes.

Shane, S. \& Venkataraman, S. (2000), The promise of entrepreneurship as a field of research. Academy Management Review, vol. 25, pp. 217-226.

Shane, S. \& Venkataraman, S. (2003), Guest editors' introduction to the special issues on technology entrepreneurship. Research Policy, vol. 32 (1), pp. 81-184.

Shepherd, D. A. \& Krueger, N. F. (2002), An intentions-based model of entrepreneurial teams' social cognition. Entrepreneurship: Theory \& Practice, vol. 27 (2).

Tenenhaus, M, Vinci, V. E., Chatelin, Y. \& Lauro, C. (2005), PLS path modeling. Computacional Statistics \& Data Analysis, vol.48 (1), pp.159-205.

Thomas, A. S. \& Mueller, S. L. (2000), A case for comparative entrepreneurship: assessing the relevance of culture. Journal of International Business Studies, vol. 31 (2), pp. 287-301.

Torres, J. L. N. \& Watson, W. (2013), An examination of the relationship between manager self-efficacy and entrepreneurial intentions and performance in Mexican small businesses. Contaduría y Administración, vol. $58(3)$, pp. $65-87$.

Valladares, P. S. D. A., Vasconcellos, M. A. \& Serio, L. C. D. (2014), Capacidade de inovação: revisão sistemática da literatura. Revista de Administração Contemporânea, vol. 18 (5), pp. 598-626.

Wetzels, M., Odekerken-Schröder, G., \& Van Oppen, C. (2009), Using PLS path modeling for assessing hierarchical construct models: guidelines and empirical illustration. MIS Quarterly, vol.33 (1), pp.177-195.

Zhao, H., Seibert, S. E. \& Hills, G. E. (2005), The mediating role of self-efficacy in the development of entrepreneurial intentions. Journal of Applied Psychology, vol. 90 (6), pp. 1265-1272. 